PhD-hallgató

PTE ÁJK

\title{
Szülők jogai és kötelességei az iskolalátogatással kapcsolatban a 20. század elején
}

\section{Parents' Rights and Obligations Regarding School Attendance at the Beginning of the 20th Century}

The parents' rights and obligations can be interpreted in two approaches according to the participation of children in public education. On the one hand, it is necessary to examine, that parents have the right to choose the appropriate educational institution for their child, on the other hand they have the obligation to ensure the compulsary schooling or education for their child. In the following I show these two eras regarding the beginning of the 20th century. My research is based on the Act XXXVIII of 1868 on public education, Act XXX of 1921 on ensuring the fullfilment of the schooling obligation, and the documents of the National Archives of Hungary Baranya County Archives. The choice of school could have been influenced by several factors, such as religious affiliation, residence, financial situation. The parents' right to choose a school was wide, so they could find the appropriate intstitutional or private school for their children. There wre problematic situations in those cases, when the parents did not want to use the existing confessional school, but the municipalty did not have the opportunity to establish public school and the parents also did not have the opportunity to educate their child at home. Formerly there were only confessional schools in Hungary, but in the middle of the 19th century it became evident that the churches can not maintain schools alone, so the role of the state is necessary. Based on the Act XXXVIII of 1868 on public education „Public education institutes can be established and maintained by confessions, associations and individuals, communities and the state." After choosing a school parents were obligated to ensure the school attendance of their child. The Act XXXVIII of 1868 on public education declared the general obligation of education or compulsary schooling. Children had to attend in everyday elementary school for 6 years and then in repeating school for 3 more years. The broad determination of the maintainers of the school supported the idea to extend the obligation of education. This meant that there was a need for more schools, regardless of the maintainers (confession, municipalty, state, etc.) in order to ensure education for most of the children. The public and ecclesiastical authorities were obliged to take action in order to ensure compulsory schooling, and there were gradually sanctions against parents. However, it did not always go smoothly, and it was not necessarily the fault of the parents or the children, but for example epidemics, world war. There were some misunderstanding regarding the attendance on religious education.

Keywords: Parents' rights and obligations, choice of school, obligation of education

\section{Bevezető}

1867 után az Osztrák-Magyar Monarchia keleti felében a szülői felügyeleti jog kérdése sajátos módon nem a magánjog körében, hanem az állam és az egyházak közötti viszony modernizálása 
kapcsán került elő. A vegyes házasságból született gyermekek vallásának meghatározása a reformáció korától konfliktusok sorát gerjesztette a felekezetek között, és ez a küzdelem hazánkban a polgári modernizáció első (reformkori és '48-as) illetve második (az 1867. évi osztrák-magyar közjogi kiegyezést követő) hullámában nem megoldódott, hanem elmélyült. Az ún. magyar kultúrharc - melynek egyik fontos eleme a szülői jogok terjedelme, ezen belül pedig a gyermek vallásának meghatározása és ezzel kapcsolatosan az iskolaválasztás (vallásoktatás) szabadsága volt - az 1890-es években tetőzött. Eredménye az lett, hogy a szabadelvű kormányzat kénytelen volt felvállani az állam és az egyházak közötti viszony modernizálását, amely - a tervbe vett családjogi kódex helyett - a polgári házasságról (1894. évi XXXI. tc.), a gyermekek vallásáról (1894. évi XXXII. tc.), az állami anyakönyvekről (1894. évi XXXIII. tc), az izraelita vallásról (1895. évi XLII. tc.) és a vallás szabad gyakorlásáról (1895. évi XLIII. tc.) szóló törvénycikkek elfogadásához vezetett. A kodifikálatlan magyar magánjog testéből formálisan kiszakítva a házassági köteléki jog egésze, a házassági vagyonjog egy kis része, a szülői felügyeleti jog tartalmának jelentős része és az anyakönyvvezetés kérdése ezzel törvényi szabályozást nyert, és hozzájárult ahhoz, hogy a szülői felügyeleti jog terjedelmét pontosítsák, ahogy azt a népoktatásról szóló 1868. évi XXXVIII. törvénycikk megkezdte az iskolaválasztás szabadságának biztosításával. ${ }^{1}$

A gyermekek közoktatásban való részvétele szempontjából a szülők jogai illetve kötelességei két megközelítésben értelmezhetők. Egyrészt vizsgálandó, hogy a szülőnek milyen jogai vannak arra nézve, hogy gyermeke számára megválaszthassa a megfelelő oktatási intézményt, másrészt figyelmet érdemel az is, hogy milyen kötelességei vannak a tankötelesség megvalósításával kapcsolatban. Jelen tanulmányban e két területet mutatom be a 19. század utolsó és a 20. század első évtizedeire vonatkozóan a népoktatásról szóló 1868. évi XXXVIII. és az iskoláztatási kötelezettség teljesítésének biztosításáról szóló 1921. évi XXX. törvénycikkek, továbbá a Magyar Nemzeti Levéltár Baranya Megyei Levéltára Baranya vármegye és Pécs város Tanfelügyelőségének iratai alapján.

\section{Iskolaválasztás}

Az iskolaválasztás mint szülői jog több körülménytől függött. Egyrészt felekezeti iskola választását természetesen befolyásolta a vallási hovatartozás, egész pontosan a szülők vonatkozásában. Ezzel kapcsolatban utalást kell tennünk a fent említett, gyermekek vallásáról szóló 1894. évi XXXII. törvénycikkre, amely alapján a bevett vagy törvényesen elismert felekezethez, és csakis ahhoz tartozó szülők megállapodhattak abban, hogy minden gyermekük az atya vagy az anya vallását követi (1.』). Annak érdekében, hogy a rendszer szabadelvú legyen, elméletileg minden bevett vagy törvényesen elismert felekezet számára megadta a jogalkotó ezt a kedvezményt. Lényegében azonban nem tett mást, mint az egyházi reverzálisok helyett egy az állami jog által intézményesített megegyezést hozott létre. ${ }^{2}$ A vegyes vallású jegyespárok előtt a vallás szabad gyakorlatáról szóló törvénycikk egy másik utat is megnyitott. Lehetőségük volt arra, hogy saját felekezetüket elhagyva

\footnotetext{
${ }^{1}$ A magyar kultúrharc értelmezéséhez valamint az állam és az egyházak közötti viszony modernizálásának kérdéséhez Magyarországon lásd HERGER, Polgári állam és egyházi autonómia 230-301.

2 A törvénycikk elemzését lásd HERGER, Polgári állam és egyházi autonómia 280-301.
} 
a másikba átlépjenek ${ }^{3}$, és immár azonos vallásúak lévén, ne legyen szükségük a megegyezés megkötésére. A megegyezést utólag csak abban az esetben lehetett megváltoztatni, ha az egyik fél házastársa vallására tért át. A változtatás azonban - ugyanazon alakiságok mellett - csak az áttérést követően születendő, illetve a 7. életévét még be nem töltött gyermekre vonatkozhatott. A 7 évnél idősebb gyermekek a gyámhatóság beleegyezése mellett térhettek csak át szüleik vallására (3.§). A gyermekek vallásáról szóló törvénycikk ezt követően az 1868. évi LIII. törvénycikk rendelkezését ismételte meg. Ha a szülők nem éltek a megegyezés lehetőségével, a gyermekeknek nemük szerint kellett szüleik vallását követni, ha azok bevett vagy törvényesen elismert felekezethez tartoztak (2.§). Ettől való eltérésnek csak akkor volt helye, ha az egyik házastárs a másik vallására tért át (4.§), azaz a házasság utólag vált nem vegyessé. A születendő vagy 7. életévét még be nem töltött, illetve a 7 évesnél idősebb gyermekekre vonatkozó szabályozás a fentivel azonos módon történt.

Mivel a tankötelesség a 6. életévtôl kezdődött, így felekezeti oktatás választása esetén a gyermeknek már abban az intézményben kellett megkezdeni e kötelessége teljesítését, amelybe szülei beíratták. A felekezeti iskolát ők választották ki, így ebben az esetben befolyásoló tényező lehetett, hogy a szülők melyik felekezethez tartoztak. Az iskolaválasztásnak sokszor praktikusabb okai is voltak, hiszen, ha egy kisebb község csupán egyetlen iskolával rendelkezett, amelyet valamely felekezet tartott fenn, a szülők számára jelentős nehézségeket okozott volna, ha más községbe kell elvinniük gyermeküket azért, mert saját felekezetük nem tart fenn iskolát. Az ehhez hasonló problémák kiküszöbölését is jelenthette a községi vagy állami oktatási intézmények létesítése, amelyekben egyházi befolyástól mentesen folyt a tanítás, és a felekezetek csupán a hittanoktatás kapcsán jutottak szerephez.

\section{Iskolaalapítás és fenntartás}

$\mathrm{Az}$ iskolaválasztás kérdésének vizsgálata előtt elengedhetetlen az iskolaalapításra és iskolafenntartásra vonatkozó rendelkezések ismertetése, hiszen ez alapján kaphatunk képet arról, hogy a szülők milyen intézmények közül választhattak.

A 20. század kezdetén is hatályban lévő 1868. évi XXXVIII. törvénycikk részletesen szabályozta az iskolák típusait, különbséget téve közöttük fenntartók illetve alapítók szerint. A korábbi magyar gyakorlatban a felekezeti iskolák voltak jellemzőek, azonban a 19. század második felére nyilvánvalóvá vált, hogy az egyházak egyedül nem képesek ellátni a feladatot, így állami szerepvállalás is szükséges, de a felekezetekkel való kompromisszum szem előtt tartásával. ${ }^{4} \mathrm{Az}$ Eötvös József vallás- és közoktatásügyi miniszter nevéhez füződő népoktatási törvény alapján lehetősége volt a felekezeteknek iskoláikat továbbra is fenntartani és újakat alapítani, mellettük azonban már az állam, községek, társulatok és magánszemélyek is élhettek ezzel a joggal: „Népoktatási nyilvános tanintézeteket a törvény által megszabott módon állithatnak és fentarhatnak a hazában létęó" bitfelekezetek, társulatok és egyesek, községek, és az állam” (10.S). E jog gyakorlását azonban feltételekhez kötötték, amelyeket a törvény tételesen előírt. Ilyen feltétel volt például a kötelező tantárgyak megállapítása, a tanító által tanított gyermekek maximális számának meghatározása, a

\footnotetext{
3 1895. évi XLIII. tc. 5.S.

${ }^{4}$ Lásd FENYŐ, Eötvös József, Kultúra és nevelés 401-406.
} 
fiúk és a leányok elkülönített oktatása, a tanító képesítésére vonatkozó előírások és az iskolai épületekre vonatkozó biztonsági szabályok betartása. ${ }^{5}$

A törvény 14. \-a kimondta, hogy minden felekezeti iskola az állam felügyelete alatt áll. Ennek megvalósítása érdekében a királyi tanfelügyelők, akik állami tisztviselők voltak, ellenőrizték a törvényi feltételek betartását a felekezeti iskolákban is. A református felekezet részéről az állami felügyelettel kapcsolatos rendelkezést tartalmaztak az 1904. november 10. napján megnyilt budapesti Országos Református Zsinat által alkotott cikkelyek, amelyek közül a VI. kifejezetten a református köznevelésről és közoktatásról rendelkezett. A népnevelési és népoktatási intézetekről szóló részben az 1868. évi XXXVIII. törvénycikkre való hivatkozással kimondták, hogy a felekezet által felállított iskolák az egyházközség felügyelete alá helyezhetők, azonban felsőbb szinten ezek is az állam felügyelete alatt állnak, tehát az egyházi felügylet nem csorbíthatja az államit (4. S). ${ }^{6}$

Az állami felügyelet kimondása mellett az iskolafenntartók körét tágan határozták meg, így a szülők választási szabadsága szélesnek tekinthető: az 1868. évi népoktatási törvény 6. \-a alapján választhattak nyilvános vagy magán, ezeken belül is állami, községi, felekezeti, társulati, magánfenntartású iskolát, továbbá elméletben más községbe is elvihették gyermeküket iskolába; a gyakorlatban ez utóbbi lehetôség - ahogyan arról korábban szó volt - korlátozódhatott, ha a szülők ideje, anyagi ereje nem engedte, hogy távolabb fekvő iskolába vigyék gyermeküket. Nyilvános intézmény volt alapvetően az állami és községi iskola, de a magánszemélyek, társulatok, és felekezetek által alapított és fenntartott iskolák is nyilvános jellegưvé válhattak a törvényben meghatározottak szerint.

A jogpolitikai cél a községi iskolák elsődlegessé tétele volt; ezek létesülhettek új iskolákként, vagy úgy, hogy a felekezeti iskolák ilyen jellegüket elvesztették és községivé alakultak át. Ezen utóbbi esetekben is igyekeztek a felekezetekkel való együttmúködést szem előtt tartani, így elsődlegesen ott volt köteles a község iskolát állítani, ahol nem állt fenn felekezeti iskola; az így felállított községi iskolák közös tanintézetek lettek, amelyek hitfelekezeti különbség nélkül nyitva álltak a községi lakosok gyermekei részére (23-24. \$S). A községi vagyonból fenntartott felekezeti iskolákat is közös iskolává minősítették, azonban a község döntése alapján meghagyhatta a támogatásával fennálló felekezeti iskolák ilyen jellegét is, de ha így tett, hozzájárulását a továbbiakban a község iskolafenntartó felekezetei között igazságos arányban kellett megosztania vagy mindegyik irányába a támogatást megszüntetnie (25. §). A község felekezeteinek döntése alapján is alakulhatott közös iskola, amely akkor valósult meg, ha a község felekezetei ugyan képesek lettek volna fenntartani iskolájukat, mégis úgy döntöttek, hogy közös erővel megfelelőbb körülményeket tudnak biztosítani; ennek előnye az volt, hogy ilyenkor igénybe vehettek állami támogatást is (26. J). Az állam csak ebben az esetben nyújtott ekkor még támogatást a felekezeteknek, akik eddig saját erejükből, híveik támogatásával gazdálkodhattak az oktatásügy tekintetében. A negyedik eset egyfajta szankcióként volt szabályozva: az állam a felekezeti iskolák feletti felügyeleti joga keretében őrködött a korábban felsorolt törvényi feltételek betartása felett, azok be nem tartása esetén meginthette a fenntartó felekezetet; ezt követően ha a feltételeket „, $a$ bitfelekęzetek. föhatóságai a kormány által félévenkint történt három iąbeli megintés után sem teljesitenék: a kormány

\footnotetext{
5 1868. évi XXXVIII. tc. 11-13, 27-29, 55. \$S

${ }^{6}$ TÉRFI - OTTLIK, Magyar közigazgatási törvények Grill-féle kiadása, 264-265.
} 


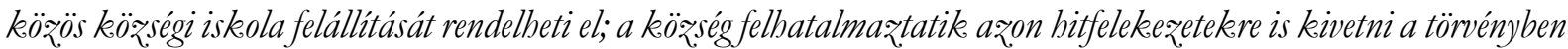
megállapitott iskolai adót, a melyek a fennebb érintett szakaszokban foglalt föltételeket, a mondott háromszori megintés után sem akarják, vagy nem képesek, saját felekezeti iskoláikra nézve teljesiteni” (15. S). Ahogy az idézett szakaszból láthatjuk, a község iskolai költségeinek fedezésére adót is jogosult volt kivetni azokra a felekezetekre, akik háromszori megintés után sem teljesítették a feltételeket.

A községi és egyéb iskolák mellett kiegészítő lehetőségként hozták létre az állami iskolákat a törvény 80. 』-a alapján. Eszerint „a közoktatási ministernek jogában és tisztében áll, bárbol, ba szüleségesnek látja, tisztán államköltségen, a helyi körülmények által igényelt népoktatási tanintézeteket állitani”. Az állami iskolákra a községi iskolák szervezési és felügyeleti szabályait kellett alkalmazni.

A községi iskolák kialakításában a szülők is szerepet vállalhattak, mivel a törvény 44-45. \a ezt számukra lehetővé tette: „Oly községben, a hol a törvény kellékeinek megfelelo” tanintézettel biró egyház. vagy egyházak hivein kivül más biffelekęzethez tartozó, legalább 30 tanköteles gyermek is van, a kiknek szülöi a fennálló felekezeti iskolákat használni nem akarják: köteles a község közös népiskolát állitani”. Ebben az esetben tehát a községet kötelezte a szülők akaratának figyelembe vételére és az eszerint való cselekvésre. Ennek két feltételeként került meghatározásra, hogy az iskolával rendelkező felekezeten kívül más felekezet legyen megtalálható a községben és hozzá legalább 30 tanköteles gyermek tartozzon, valamint, hogy az ô szüleik a meglévő felekezeti iskolát nem akarják használni. A következő szakasz ez alól engedett eltérést: „Ott pedig, a hol a más hitfelekezetekhez tartozó gyermekek száma a 30-at el nem éri, ęen gyermekek is, a mennyiben szülöík oktatásukról más úton nem gondoskodnának,

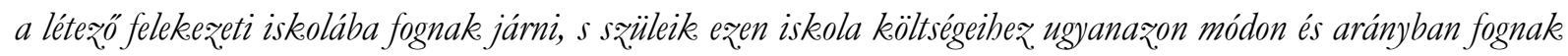
járulni, mint azon bitfelekezzet tagjai, mely az iskolát fentartja”. Ha az iskolával nem rendelkező felekezethez tartozó gyermekek 30-nál kevesebben voltak, a község nem volt köteles számukra iskolát felállítani, viszont a szülők még ekkor is dönthettek úgy, hogy más felkezet iskolája helyett magánúton gondoskodnak gyermekük taníttatásáról. A szülők tehát alapesetben rendelkezhettek úgy, hogy más felekezet iskolájába nem járatják gyermeküket. Akik a magánoktatást nem akarták vagy nem tudták igénybe venni, kénytelenek voltak gyermeküket más felekezet iskolájába járatni. ${ }^{7}$

Összességében a községek néhány kivétellel nem jeleskedtek mint iskolafenntartók, továbbá az egyházak is ragaszkodtak a felekezeti iskolákhoz még azok rossz viszonyok közötti fennállása esetén is, ́́gy egyrészt ezek az intézmények maradtak túlsúlyban, másrészt a minőségük sem nőtt állami támogatás folytán, mivel nem hajlottak az összefogásra a jobb körülmények biztosítása érdekében. Az 1868-as népoktatási törvény rendelkezései a 20. század kezdetén még mindig meghatározták az iskolák helyzetét. A törvénnyel kapcsolatos reform munkálatok között kiemelkedő helyen állt az iskola építések területe, amelyet Wlassics Gyula vallás- és közoktatásügyi miniszter kezdett meg az 1890-es években. Baranyai vonatkozásban a századfordulón két iskolaépítési akcióra irányuló lépéseket dokumentáltak, 1896-ban és 1906-ban. Utóbbi munkálatok során a Baranyavári Járás fôszolgabírója Albertfalu községgel kapcsolatban említést tett a szülők tiltakozásáról az állami iskolákkal szemben: „Albertfalu községben (...) a bitfelekeezet iskoláját semmi szin alatt át nem adja - sốt, az is bizonyos, hogy ha az állam mégis állitana fel állami iskolát, a sqülók nem fogják gyermekeiket az állami iskolába járatni”. ${ }^{8}$ Ebből is láthatjuk, hogy a felekezeti iskolák olyan mélyen

\footnotetext{
7 1868. évi XXXVIII. tc. 44-45. \$s

${ }^{8}$ MNL BaML IV. 401. b) Bvm. főisp. ált. ir. 14/1907, Főszolgabírói jelentések
} 
gyökereztek a társadalomban, hogy hosszú időnek kellett eltelnie ahhoz, hogy a szülők bizalmukat más intézmények felé is fordítsák.

\section{Tankötelesség}

Az iskola és annak típusa megválasztása után a szülőnek kötelessége volt gondoskodni arról, hogy gyermeke megfelelően is látogassa az iskolát. Az 1868. évi XXXVIII. törvénycikk a népiskolai közoktatás tárgyában - hazánkban először - előírta az általános tankötelezettséget, amelyet fiúkra és lányokra egyaránt alkalmazni kellett. A tanköteles kor 6-tól 12 éves korig tartott, ezt mindennapi elemi iskolában kellett teljesíteni, ezt követően a gyermekeknek 15 éves korukig ismétlő iskolába kellett járni. A korábban bemutatott iskolafenntartók körének széles meghatározása is azt az elképzelést támogatta, hogy a tankötelességet minél tágabb réteg számára biztosíthassák. Ez a gyakorlatban azt jelentette, hogy lényegtelen volt, ki a fenntartó (egyház, község, állam, egyesület, magánszemély), de legyen minél több iskola, ahova a gyermekeket el tudják helyezni anélkül, hogy azok túlzsúfolttá válnának. Az elgondolás azonban nem feltétlenül valósult meg mindenhol, így például Pécs polgármestere 1898. február 20-án kelt levelében arról számolt be, hogy a város iskoláiban egy osztályba 80-100 gyermek jut, és a bővítést (akár tanterem, akár tanerő tekintetében) nem engedhetik meg maguknak. ${ }^{9}$

A tankötelesség betartása érdekében mind az állami, mind az egyházi tanügyi igazgatás szervei kötelesek voltak fellépni. A jogalkotói szándék arra irányult, hogy a szülők ne azért írassak gyermeküket felekezeti iskolába, vagy döntsenek a házi tanító alkalmazása mellett, hogy ezzel bújjanak ki a tankötelesség tényleges teljesítése alól. Így a népoktatási törvény 6. \-a elöírta, hogy az „,iskolai hatóságok is kötelesek ügyelni, hogy az ily gyermekek (értsd: minden gyermek, függetlenül attól, hol teljesíti a tankötelezettséget) legalább is oly oktatásban rész̧esüljenek, minöt a törvény szuerint berendez̧ett nyilvános elemi népiskolában nyerhetnének, és a kötelez̨ett évek tartamáig tanittassanak.”. Ezzel megerôsítették a tankötelesség időtartamának fontosságát és hangsúlyt helyeztek az oktatás minőségének biztosítására, amelyet megerősített a következő szakasz azon rendelkezése, miszerint „A háznál tanult növendékelk kötelesek évenkint vizsgát tenni le valamely megfeleló nyilvános tanintézet illetö tanitói elött”. A népoktatási intézetekre vonatkozó szabályok kialakítása során igyekeztek biztosítani a kereteit annak, hogy a megfelelő tartalmú és időtartamú oktatás biztosítva legyen minden tanköteles gyermek számára, bármely intézményi formát veszik is igénybe szülei, továbbá akkor is, ha úgy döntenek, hogy magánúton gondoskodnak a gyermekük oktatásáról. Ez utóbbi esetben a gyermekek kötelesek voltak vizsgát tenni nyilvános tanintézet tanítói előtt, a szülők kötelessége pedig „erröl a belybeli iskolai šéknek bélyegmentes bironyitványt elómutatni” (6. §).

A hatóságok mellett természetesen a szülőknek is tevékenyen közre kellett működni. A törvény 1. \$-a meghatározta, hogy a tanköteles kor idejére „Minden szülő vagy gyám, ide értve azokat is, kiknek házában gyermekek mint mestertanitványok vagy házi szolgák tartatnak, kötelesek gyermekeiket vagy gyámoltjaikat ( $b a$ - ahogyan a korábban megfogalmazottak szerint arra lehetőségük volt - nevelésökeröl a háznál vagy magán tanintézẹtben nem gondoskodtak) nyilvános iskolába járatni”. Ez deklarálta a szülők

\footnotetext{
${ }^{9}$ MNL BaML IV. 401. a) Bvm. főisp. biz. ir.. 290/1898, Majorossy polgármester 1898. február 20.-i levele
} 
mellett a gyámok kötelességét is, továbbá említést tett azokról, akik iparostanoncképzésben mesterként múködtek.

A tankötelezettség elmulasztása esetére kilátásba helyezett szankciókat fokozatosan kellett alkalmazni a szülőkkel szemben, annak érdekében, hogy gyermekeiket iskolába járassák. Ennek indoka az lehetett, hogy nagyobb érdek füződött a gyermek oktatásban való részvételének előmozdításához, mint a szülő megbüntetéséhez. Ennek értelmében „Ha a szü̈lo" (gyám vagy gazda) a tankötelez̨ett növendéket az iskolától visszatartja: ebbeli kötelességének teljesitésére komolyan figyelmeztetendô"”. Tehát elsőként egy erkölcsi célzatú intést alkalmaztak, ha ez nem volt elegendő, további következményként pénzbüntetések következtek: „És ha az e czélra szolgálható erkölcsi es₹łö̈rök felhasználása sikertelennek bizonyulna be, s a tankötelezett növendék az iskolától továbbra is visszatartatnék: a kötelességét ekként teljesitni nem akaró szülö (gyám vagy gazda) elsö iz̨ben 50 krra, második iz̧ben 1 forintra, harmadik ižben 2 frtra, negyedik ižben 4 frtra büntettessék, ą iskolai pénztár javára”. Amennyiben az anyagi szankciók sem érték el a kívánt hatást, akkor az iskolaszék feljelentésére a hatóság gyám kirendelését kezdeményezhette gyermek számára: „Söt ha még ezen négyszeri büntetés sem téritené a sæülöt (gazdát vagy gyámot) kötelességének teljesitésére: akekor az illetô iskolai szék erröl a felsöbb iskolai batóságnál jelentést tesz, mely az̧tán az iskolától visszatartott tanköteles gyermek számára a községi hatóságnál kïlön gyám rendelését is szorgalmazhatja" (4. \$). ${ }^{10}$

Bár az 1868. évi népoktatási törvény már elég széleskörűen rendezte a tankötelesség teljesítésének részleteit és elmulasztásának következményeit, az elkövetkező évtizedekben nem feltétlenül jutott érvényre mindenhol hatása. A gyermekek kimaradása az iskolából több körülményre volt visszavezethető, így például a mezőgazdasággal foglalkozó területeken a munkálatokban való részvételre. Az első világháború idején az iskolák helyzete is nehéz volt, a tanítók bevonultak, több esetben épületeikben katonákat szállásoltak el.

A levéltári források alapján tudjuk, hogy Sásd római katolikus elemi iskolájában hátráltatta az iskola munkáját, hogy az iskolaépületet a katonaság igénybe vette. A sásdi plébániáról a tanfelügyelőnek érkezett 1919. október 11-i levelében Sqü̈s József plébános arról számolt be, hogy az iskola két tantermét a katonai hatóság rendelete folytán katonák foglalták be, ezért az oktatás már egy hónapja szünetel. A plébános intézkedések meghozatalára kérte a tanfelügyelőt, és felhívta figyelmét, hogy ha a katonák tovább maradhatnak, akkor Sásdon a tanítás teljesen szünetelni fog. Hozzátette azt is, hogy „Már egyes szülök zugolódnaks nagyon sürgetik nálam a tanitás mielóbbi megkęquését, annál is inkább mert a tantermek már a báborús idôk alatt is nagyon sokszor igénybe vétettek tartalék kórházaknak, s a tankötelesek csak. felváltva lettek. oktatva más helyiségben lévö terem sұük. mérete miatt”. Sándor Lajos tanfelügyelő a kérést azonnal továbbította, hozzátéve, hogy „a sұülók aggodalma méltányolandó, ha ažt látják, hogy gyermekeik az iskolázás teljes hiányában szellemi és erkölcsi elvadulásnak vannak kitéve”, valamint a tanfelügyelő javasolta, hogy „legalább az egyik tantermet a beszállásolás alul mentesitsék, hogy a tanitás váltakozó rendszer mellett megkezdhetö legyen". ${ }^{11}$

\footnotetext{
10 1868. évi XXXVIII. tc. 4. S

${ }^{11}$ MNL BaML VI. 502. Bvm. és Pécs v. Tanfelügyelőségének iratai, 18/1919, Szűcs József plébános 1919. október 11i levele
} 


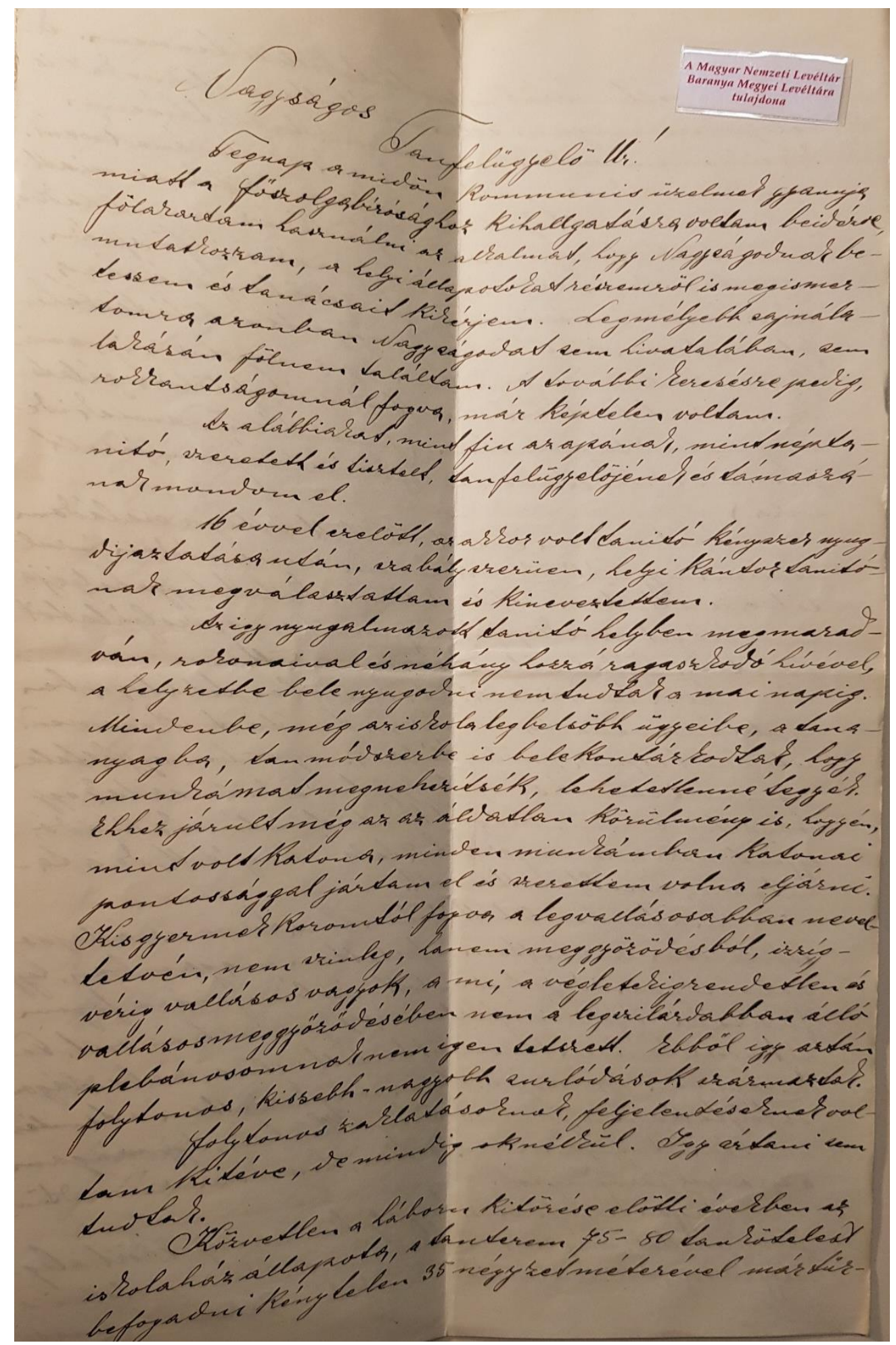

1. kép: Hering József tanító 1919. november 27-i levele, 1. oldal, MNL BaML VI. 502. Bvm. és Pécs v. Tanfelügyelőségének iratai 


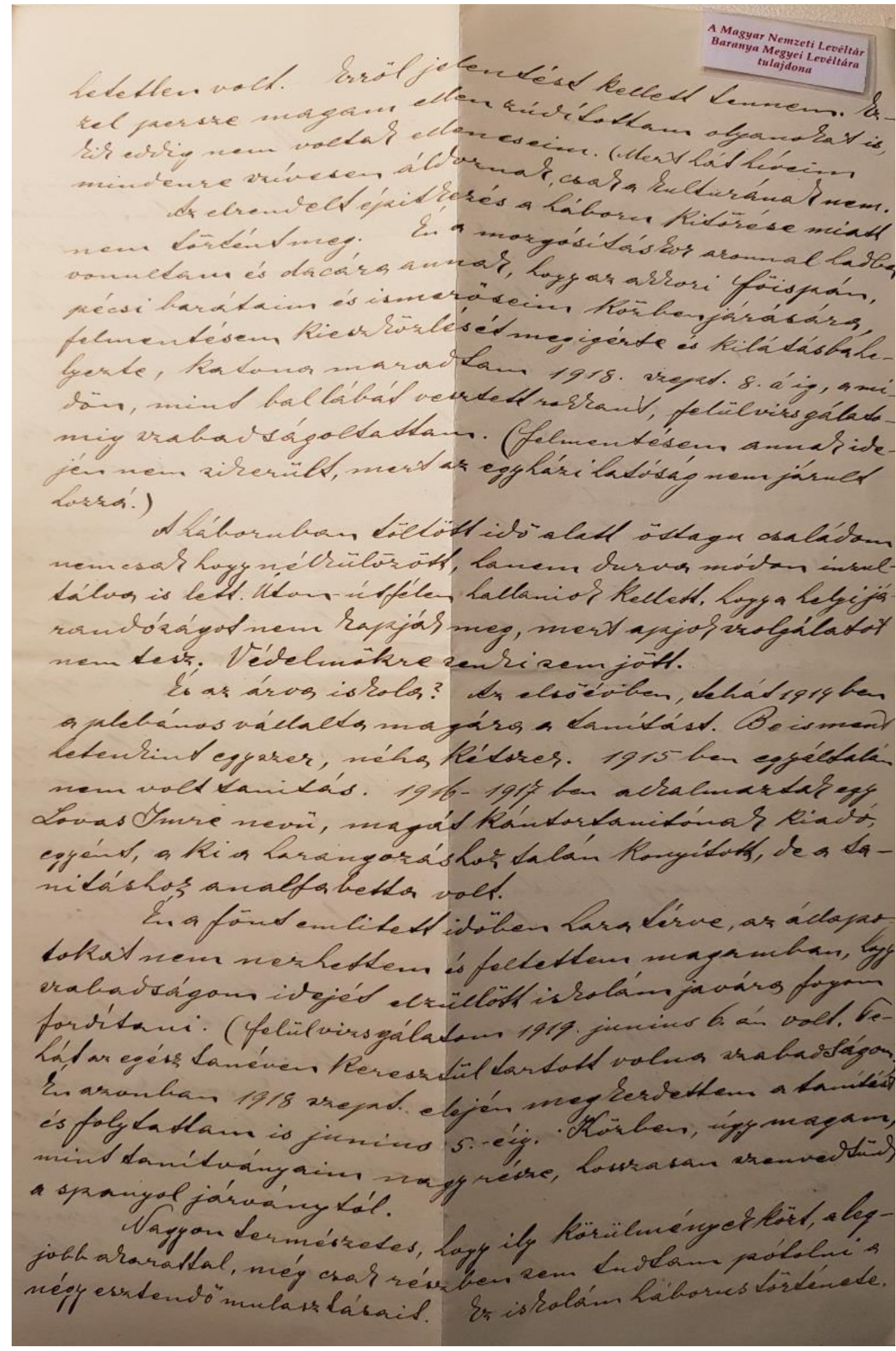

2. kép: Hering József tanító 1919. november 27-i levele, 2. oldal, MNL BaML VI. 502. Bvm. és Pécs v. Tanfelügyelőségének iratai 


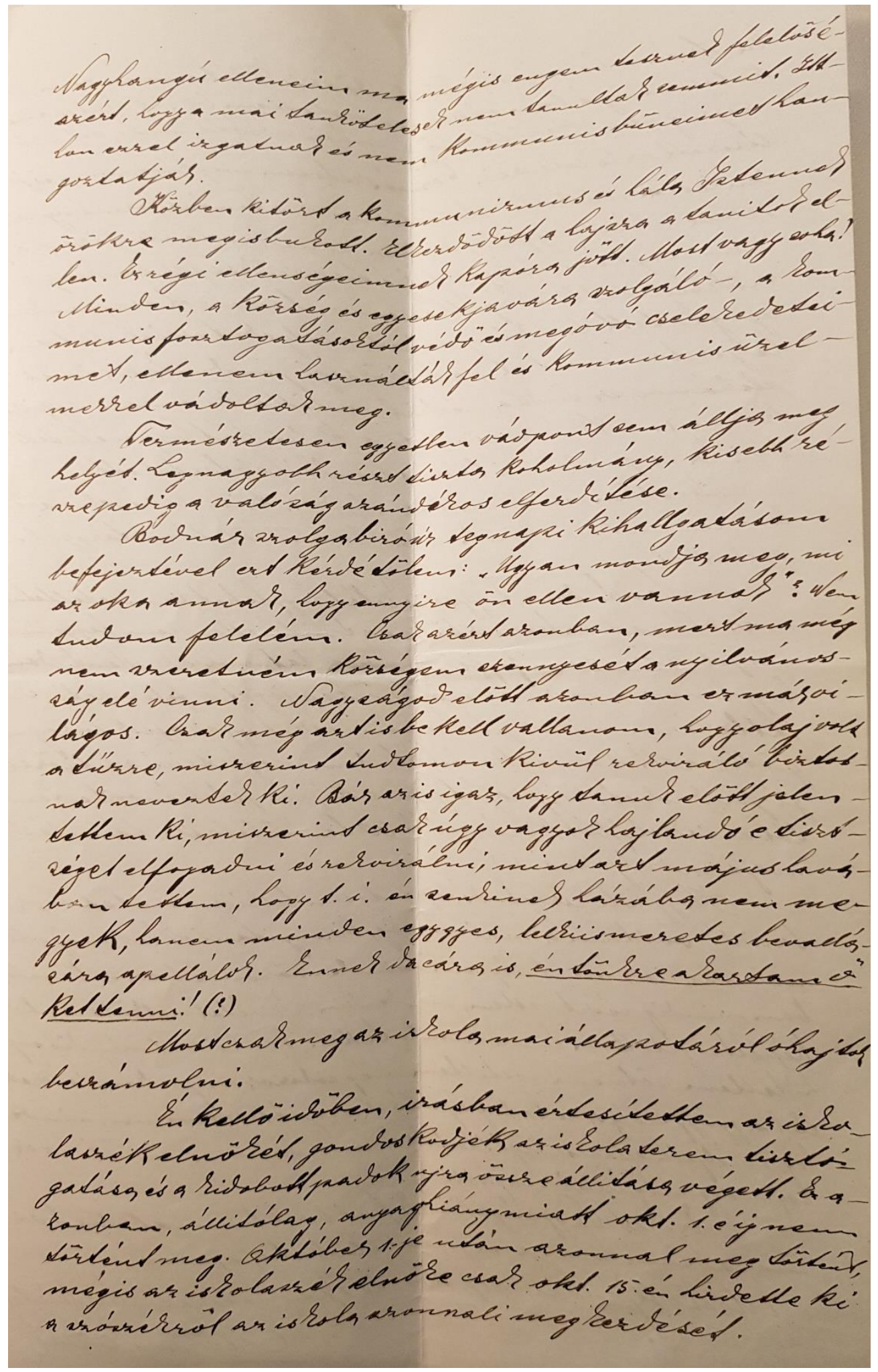

3. kép: Hering József tanító 1919. november 27-i levele, 3. oldal, MNL BaML VI. 502.

Bvm. és Pécs v. Tanfelügyelőségének iratai 


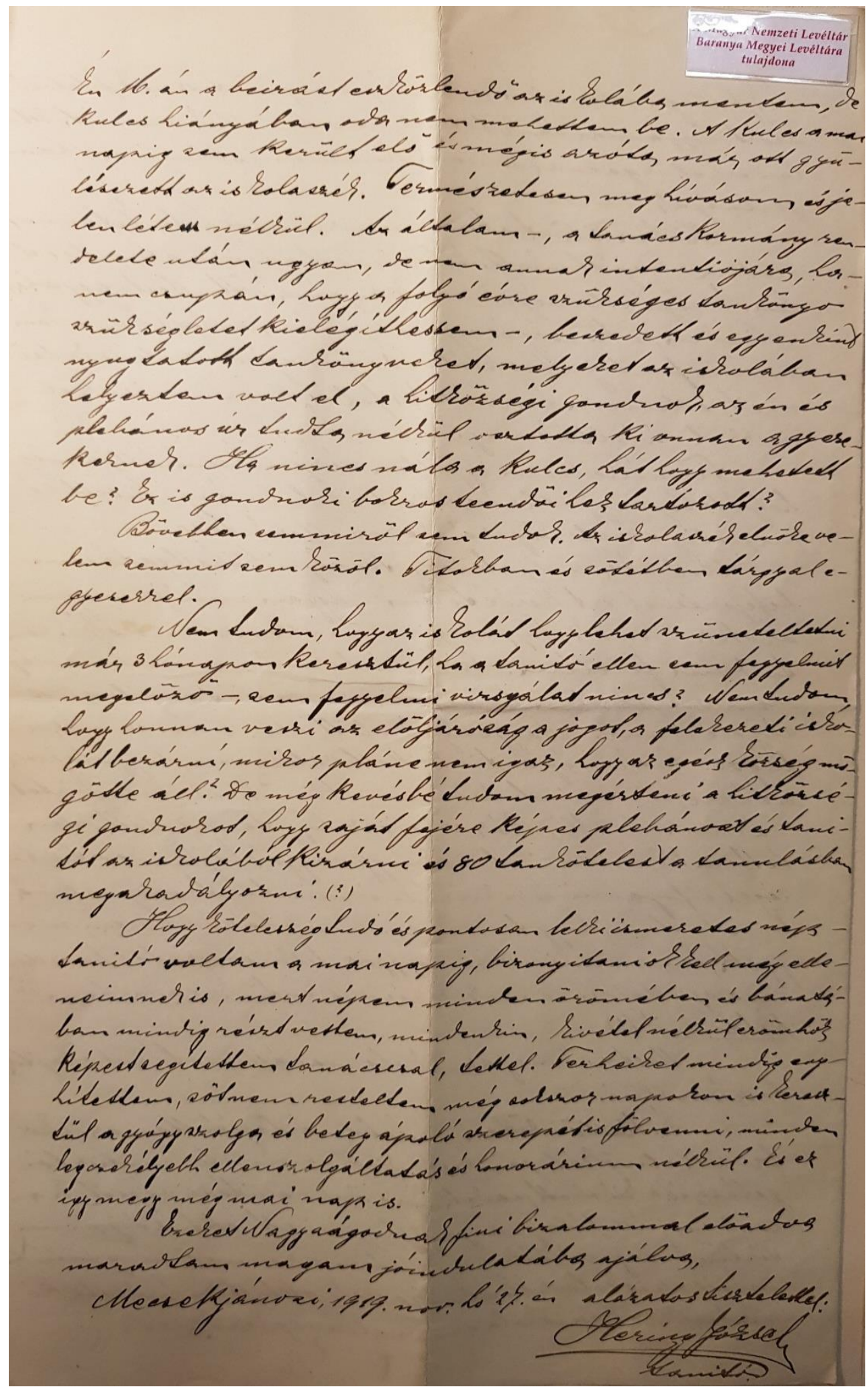

4. kép: Hering József tanító 1919. november 27-i levele, 4. oldal, MNL BaML VI. 502. Bvm. és Pécs v. Tanfelügyelőségének iratai 
A háború okozta nehéz helyzetről számolt be Hering Jórsef mecsekjánosi római katolikus felekezeti tanító is a tanfelügyelőhöz intézett panaszában. A tanító elmondása szerint a háború kitörésekor azonnal bevonult, majd 1918 szeptemberéig nem is tért haza. Az iskola az első évben a plébánosra lett bízva, aki hetente egyszer, legfeljebb kétszer tanította a gyermekeket, majd 1915-ben egyáltalán nem volt tanítás. Ezt követően „1916-1917-ben alkalmaztak egy Lovas Imre nevü, magát kántortanitónak kiadó egyént, aki a harangozáshoz talán konyitott, de a tanitáshoz analfabéta volt'. A tanító 1918-ban hazatért hadirokkantként, így szabadságolták további kivizsgálásig, amelyre 1919 júniusában került sor, tehát egy teljes tanévig szabadságon lett volna, de elmondása szerint ezt az idôt arra fordította, hogy az iskola helyzetén javítson és a tanítást folytatta, bár ebben hosszú időn át akadályozta az ún. spanyol járvány, amelyet ő is és a gyermekek is elkaptak. Így négy évnyi lemaradást kellett behoznia a tanítónak, hogy a tankötelesek megtanuljanak írni-olvasni. ${ }^{12}$ Láthatjuk, hogy ilyen idôkben nem feltétlenül csak a szülőn vagy a gyermeken múlt, ha nem járt iskolába, hanem több körülmény (háború, járvány) együttes következménye volt.

A háborút követően a vallás- és közoktatásügyi miniszterek az iskolarendszer helyreállítása érdekében is intézkedéseket tettek. Vass József miniszter nevéhez kötődik az 1921. évi XXX. törvénycikk az iskoláztatási kötelezettség teljesítésének biztosításáról, amely részletesebben szabályozta a tankötelezettség nemteljesítését. A törvény 1. \-a megerősítette és részletezte a tankötelezettség tartamát azzal, hogy „Minden gyermek gondviselöje (szülo”, gyám, gazda) - amennyiben ežn törvény kivételt nem tesz. - köteles a gondviselése alatt álló gyermeket a gyermek batodik életévének betöltését követö kilenc tanéven át nyilvános iskolai oktatásban, még pedig 1. hat tanéven át elemi népiskolai, 2. továbbá három tanéven át továbbképzón (ismétló) népiskolai oktatásban részesittetñ”. Ekkor a tankötelezettség időtartamában és felosztásában nem történt változás. Hasonlóan változatlan maradt a tankötelezettséghez kapcsolódó iskolaválasztás: a 4. \alapján „Mindenki (szülő, gondviselő), akinek gondviselésében iskoláatatási kötelesség alatt álló gyermek van, köteles a gyermeket népiskolába, illetöleg más nyilvános iskolába beiratni és gondoskodni arról, hogy a gyermek az iskolába rendesen járjon; jogában van azonban a gyermeket akár lakóbelyén, akár más községben levö és bármilyen jellegü nyilvános iskolába beiratni és járatni”.

A törvény lehetővé tette, hogy a gondviselő által be nem íratott gyermekeket az illetékes iskolai hatóság hivatalból beírassa az iskolába. Ennek első esete az volt, ha az otthon vagy magánintézetben tanuló gyermek - aki számára továbbra is elő volt írva, hogy köteles nyilvános intézet tanítói előtt vizsgát tenni - az éves vizsgán alacsonyabban teljesített, mint a nyilvános iskolába járók számára előírt szint. A második esete, ha a szülő vagy gondviselő nem íratta be gyermekét nyilvános iskolába és nem is igazolta, hogy más módon gondoskodna gyermeke taníttatásáról; ekkor a szülőt elôször határidő tűzésével felhívták ennek teljesítésére, majd amennyiben a megadott határidőn belül a gondviselő nem intézkedett, ôt a hatóság pénzbüntetéssel, illetve behajthatatlansága esetén elzárással büntette, ezt követően a községi előljáróság megkeresésére az illetékes elsőfokú iskolai hatóság hivatalból beírta a gyermeket az iskolába. Ha a hivatalból beírt gyermek a tanév folyamán igazolatlanul mulasztott, gondviselójével szemben alkalmazható volt a pénzbírság, illetve elzárás, azzal, hogy ekkor intésnek nem volt helye (8. $\left.\int\right)$.

\footnotetext{
${ }^{12}$ MNL BaML VI. 502. Bvm. és Pécs v. Tanfelügyelőségének iratai, 114/1919, Hering József tanító 1919. november
} 27-i levele 
A törvény rendelkezései előre lépésnek tekinthetôk abban az értelemben, hogy már rendelkeztek arról is, mi történjen a tankötelezettség elmulasztása okán behajtott bírságokkal. A 14. \szerint azok ,teljes egészüikben az iskolába járó szegény gyermekek segélyezésére fordítandók, még pedig azon község szegény tanulói javára, amely községböl azok behajtattak. A befolyt összegek felhasználásáról këtelesek az. elsöfokú iskolai hatóságok. minden tanitási év végén szabálysz̨erü számadásban a közigazgatási bizottságnak. elszámolni. A segélyezés szülkségét és mértékét a rendelkezésre álló anyagi eszközö̈khöz képest az elsôfokú iskolai batóság a tanitóval, illetöleg tanitói testülettel egyetértöleg állapitja meg, de a segélyezés csakis természetben (tankönyvek és tanes₹közök, rubázat, cipö, beteg gyermekeknek gyógyszer stb.) történhetik”. ${ }^{13}$ A kutatás jelenlegi állása szerint nem áll rendelkezésre arról levéltári forrás, hogy a bírságok segélyként történő felhasználását végrehajtották-e, valamint ha igen, milyen módon valósították ezt meg.

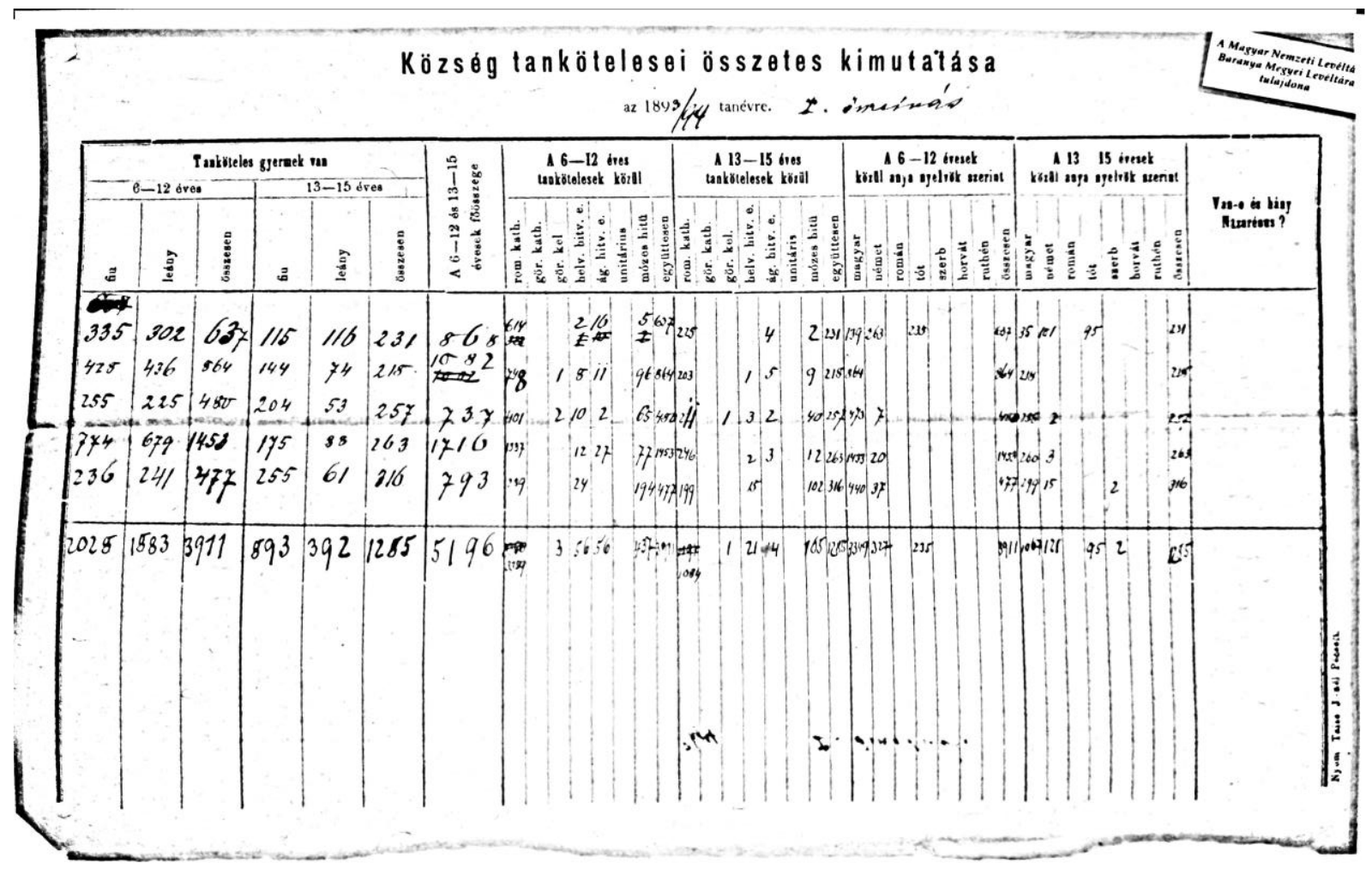

5. kép: Pécs tanköteleseinek kimutatása, MNL BaML VI. 502. Bvm. és Pécs v. Tanfelügyelőségének iratai, 319/1893

A tankötelességhez kapcsolódik az iskolai hitoktatás és az azon való részvétel kérdése. Már az 1868. évi népoktatási törvény alapján a felekezeti iskolák mellett a többi iskolában is kötelező tárgyként szerepelt a hittanóra, amelyről a felekezetek gondoskodtak a hozzájuk tartozó gyermekek számára. Megvalósítása érdekében többször készítettek összeírást a tanulókról, hogy mindenki a vallásának megfelelő vallásoktatásban részesülhessen. Ezt a reformátusok oly módon szabályozták, hogy előírták, a tanév megkezdését megelőző két hónappal össze kell írni a tanköteleseket, szükség

13 1921. évi XXX. tc. 1, 4, 8, 14. JS 
esetén a világi hatóság segítségével (16.§). Erről az iskolaszék köteles nyilvántartást vezetni, amelyben feltünteti, hogy kik a református vallású tanköteles gyermekek és ők mely iskolába járnak. ${ }^{14}$ De nem csupán a református, hanem a többi felekezet vonatkozásában is fontos volt elkészíteni az összeírásokat a tanulókról a hittanórák megfelelő lefolytatása érdekében. A levéltári iratok között megtalálhatjuk ezeket az iratokat, amelyekben név szerint felsorolták, mely iskola mely osztályában milyen vallású gyermekek tanulnak. ${ }^{15} \mathrm{~A}$ római katolikus vallásúakról ilyen összeírás külön nem készült, csupán összesítetten az egész községre vonatkozóan, ennek valószínúleg az lehet az oka, hogy mindenki más, aki nem szerepelt a névsorokban, ide tartozott, hiszen a vizsgált korszakban Baranyában ez volt többségi vallás.

A tanköteles gyermekek hitoktatásával kapcsolatban a baranyai tanfelügyelő, ekkor Schneider István egyeztetett az illetékes egyháziakkal (tehát minden felekezettel, amely Pécsett tanköteles korú hívekkel rendelkezett), részletesen megtárgyalva minden pécsi iskolára vonatkozóan a hitoktató személyét, fizetését és az órák időpontját, valamint értesítették egymást azon tanulókról, akik a hittanórákat nem látogatták rendszeresen. ${ }^{16}$ A vallásoktatásról a törvény alapján a felekezet feladata volt gondoskodni, ennek megfelelően hozzájárulásuk nélkül nem is volt kinevezhető a hitoktató. Ezek ellenére természetesen nem volt zökkenőmentes a megvalósítás, erről számolt be egy evangélikus lelkész 1912-ben, Schneider István baranyai tanfelügyelő igazgatónak írt levelében: „ $A$ z ágostontéri iskolai, különösen alsóbb osztályu tanitványaim, söt szüleik is gyakran panas₹kodnak, hogy gyermeküket a róm. kath. bittanórákon bentfogják, vagy mondjuk úgy a dolgot, a gyermekek kénytelenek bent maradni a róm. kath. hittanórákon, mert a hittanórák a délelött vagy délután közepén tartatnak, s nincsen terem, hol a nem róm. kath. tanulók egész idó alatt meghiródhatnának. A róm. kath, hittanórákon bentmaradó ev. gyermekeket a zután - nem mondom hogy tudatosan vagy rossz̧biszemüleg - az illetö bitoktató úr felszólítja s feleltet velük, s ha-ami természetes is - felelni nem tudnak, megbünteti öket. Mondom, lehetséges, hogy az illetö bitoktató úr egész jóhiszemüleg jár el, azt gondolván, hogy az elötte levő gyermeksereg mind róm. kath. vallásû". ${ }^{17}$

\section{5. Összegzés}

Az iskolaválasztást több körülmény befolyásolhatta, így például vallási hovatartozás, lakóhely, anyagi helyzet. Ezt figyelembe véve a szülők iskolaválasztáshoz való joga széles körben lett kialakítva, így mindenki megtalálhatta a számára leginkább megfelelő intézményi formát, vagy magántanítót is alkalmazhatott. Problémák ezzel kapcsolatban leggyakrabban ott merültek fel, ahol a meglévő felekezeti iskolát a szülők nem kívánták igénybe venni, ugyanakkor a községnek nem volt lehetősége közös iskolát felállítani, és más módon nem tudtak gondoskodni gyermekük tankötelességének biztosításáról.

Az általános tankötelességet hazánkban az 1868. évi népoktatási törvény vezette be. Teljesítésének biztosítása érdekében állami és egyházi hatóságok is felléphettek, a szülőkkel

\footnotetext{
14 TÉRFI - OTTLIK, Magyar közigazgatási törvények Grill-féle kiadása, 266-267.

15 MNL BaML VI. 502. Bvm. és Pécs v. Tanfelügyelőségének iratai, 319/1893, 448/1894, 449/1894, 510/1894, 522/1894, 523/1894, 531/1898, 532/1898

16 MNL BaML VI. 502. Bvm. és Pécs v. Tanfelügyelőségének iratai, 43/1893, 413/1894, 563/1894, 547/1897, 506/1898, 534/1898, 3/1912, 4/1912, 32/1912, 40/1912

${ }^{17}$ MNL BaML VI. 502. Bvm. és Pécs v. Tanfelügyelőségének iratai, 175/1912
} 
szemben fokozatos szankciókat alkalmazhattak. Ennek ellenére a folyamat nem ment mindig gördülékenyen, nem feltétlenül a szülők hibájából, így például járványok, háborús állapotok nehezítették az iskolalátogatást, valamint a hittanórákon való részvétellel kapcsolatban is akadtak félreértések.

\section{Felhasznált források és irodalom}

MNL BaML VI. 502. Bvm. és Pécs v. Tanfelügyelőségének iratai, 43/1893, 413/1894, 563/1894, 547/1897, 506/1898, 534/1898, 3/1912, 4/1912, 32/1912, 40/1912, 175/1912, 319/1893, 448/1894, 449/1894, 510/1894, 522/1894, 523/1894, 531/1898, 532/1898, 114/1919, 18/1919

MNL BaML IV. 401. a) Főisp. biz. iratai, 290/1898

MNL BaML IV. 401. b) Bvm. főisp. ált. iratai, 14/1907

1868. évi XXXVIII. törvénycikk a népiskolai közoktatásról

1894. évi XXXII. törvénycikk a gyermekek vallásáról

1921. évi XXX. törvénycikk az iskoláztatási kötelezettség teljesítésének biztosításáról

Herger Csabáné: Polgári állam és egyházi autonómia a 19. században. Budapest 2010

TÉRFI Gyula - OTTLIK Géza: Magyar közigazgatási törvények Grill-féle kiadása. Budapest 1911

FENYŐ István: Eötvös József, Kultúra és nevelés. Budapest 1976 